\title{
STIMULASI KEMAMPUAN MOTORIK HALUS ANAK USIA 4-5 TAHUN MELALUI KEGIATAN SENI RUPA
}

\author{
Nurul Kusuma Dewi, Surani \\ PG PAUD, FKIP, Universitas Sebelas Maret, TK Negeri Pembina Surakarta \\ e-mail: kusuma.dewi@staff.uns.ac.id ${ }^{1 *}$, surani329@gmail.com
}

\begin{abstract}
Abstrak
Penelitian ini bertujuan untuk menstimulasi kemampuan motorik halus anak usia 4-5 tahun. Penelitian dilakuakn pada bulan Juli-Oktober 2018 di Kelompok A TK Negeri Pembina Surakarta. Penelitian ini menggunakan pendekatan kualitatif dengan jenis penelitian tindakan kelas (PTK). Model penelitian tindakan kelas yang digunakan adalah Kemmis dan Mc Taggart yang meliputi empat tahapan, yaitu: perencanaan, pelaksanaan, pengamatan, dan refleksi. Subyek penelitian adalah anak usia 4-5 tahun berjumlah 21 anak yang terdiri dari 1 anak laki-laki dan 10 anak perempuan. Data penelitian berupa data kualitatif dan sumber data penelitian adalah guru dan anak. Data penelitian diperoleh menggunakan teknik observasi, wawancara, dan dokumentasi. Teknik uji validitas data penelitian menggunakan triangulasi teknik dan triangulasi sumber. Data penelitian dianalisis menggunakan model interaktif Milles dan Huberman yang terdiri dari empat tahapan, yaitu pengumpulan data, reduksi data, penyajian data dan verifikasi data. Hasil penelitian yaitu: (1) indikator motorik halus anak yang meliputi koordinasi mata dan tangan, kekuatan jari tangan, dan kelenturan pergelangan tangan meningkat; (2) kegiatan seni rupa yang dapat diterapkan pada anak usia dini adalah mewarnai, menggambar, melukis, menjiplak, membentuk, menempel, meronce, dan figer painting; serta (3) kemampuan motorik halus anak usia 4-5 tahun dapat distimulasi melaluli kegiatan seni rupa.
\end{abstract}

Kata Kunci: motorik halus, kegiatan seni rupa, usia 4-5 tahun

\section{STIMULATION OF FINE MOTOR SKILLS OF CHILDREN AGE 4-5 YEARS THROUGH VISUAL ART ACTIVITIES}

\begin{abstract}
This study aims to stimulate the fine motor skills of children aged 4-5 years. this research was carried out in July-October in the Surakarta A Group of State Kindergarten coaches. This study uses a qualitative approach to the type of classroom action research (CAR). The classroom action research model used is Kemmis and Mc Taggart which includes four stages, namely: planning, implementation, observation, and reflection. Research subjects were 21 children aged 4-5 years consisting of 1 boy and 10 girls. Research data in the form of qualitative data and research data sources are teachers and children. Research data was obtained using observation, interview, and documentation techniques. The technique of testing the validity of research data using technical triangulation
\end{abstract}


and source triangulation. The research data was analyzed using Milles and Huberman's interactive model consisting of four stages, namely data collection, data reduction, data presentation and data verification. The results of the study are: (1) children's fine motor indicators which include eye and hand coordination, finger strength, and increased wrist flexibility; (2) art activities that can be applied to early childhood are coloring, drawing, painting, tracing, forming, sticking, rooting, and figer painting; and (3) fine motor skills of children aged 4-5 years can be stimulated through art activities.

Keywords: motor skill, visual arts activities, 4-5 years

\section{PENDAHULUAN}

Pendidikan anak usia dini merupakan pendidikan dasar bagi kehidupan setiap anak. Pendidikan pada anak usia dini tidak hanya menanamkan pengetahuan, namun juga membentuk karakter dan menyiapkan anak untuk jenjang pendidikan selanjutnya. Oleh karena itu, stimulasi yang diberikan kepada anak usia dini harus sesuai dengan konsep perkembangan anak. Aspek perkembangan anak usia dini meliputi: aspek nilai moral dan agama, sosial emosional, bahasa, kognitif, seni, dan fisik motorik baik motorik kasar dan halus. Semua aspek perkembangan anak tersebut dapat distimulasi melalui kegiatan pembelajaran.

Salah satu aspek yang paling penting dikembangkan adalah motorik halus. Kemampuan motorik halus anak usia dini sering kali diabaikan dan dianggap tidak terlalu penting. Padahal kenyataannya, kemampuan motorik halus anak menjadi dasar atau pondasi kemampuan menulis. Kematangan motorik halus yang dimiliki anak akan membantu anak mengembangkan kemampuan menulis. Standar kemampuan motorik halus anak usia 4-5 tahun, meliputi: (1) koordinasi mata dan tangan; (2) kelenturan pergelangan tangan; dan (3) kekuatan dan kelenturan jari tangan (Kemdikbud, 2015: 11). kemdikbud menjabarkan kemampuan motorik halus anak berhubungan dengan perkembangan otot jari dan pergelangan tangan. Sedangkan Yamin dan Sanan (2013: 101-103) menjelaskan kemampuan motorik halus anak meliputi: menggenggam, memegang, merobek, menggunting, dan koordinasi mata serta tangan.

Dilapangan diperoleh data bahwa kemampuan motorik halus anak masih belum berkembang secara maksimal. Hal ini dibuktikan, dari berbagai kegiatan motorik halus anakanak masih belum bisa menggunting pola sederhana, mewarnai dengan cara menggenggam krayon, dan belum mampu menjimpit biji-bijian untuk dimasukan kedalam botol. Anak-anak masih cenderung memeasukan bijibijian kedalam botol dengan cara menggenggam.

Kemampuan motorik halus anak usia 4-5 tahun dapat distimulasi dengan berbagai kegiatan pembelajaran yang menyenangkan, salah satunya melalui kegiatan seni rupa. Menurut Soetedja, kegiatan seni rupa merupakan bidang yang memfokuskan pada pencitraan objek yang dibuat, ditunjukkan, dan 
diapresiasi (Mulyani, 2017: 61). Pendapat Soetedja diatas menjelaska bahwa seni rupa merupakan hasil karya yang dibuat dalam bentuk sebuah produk yang dapat dinikmati oleh orang lain. Sedangkan menurut Dyson dan Richards seni rupa anak usia dini merupakan coretan anakanak yang berisi benih-benih dikemudian hari akan tumbuh mekar ke dalam aktivitas membaca dan menulis (Seefeldt dan Wasik, 2008). Pendapat Dyson dan Richards diatas menjelaskan bahwa kegiatan seni rupa merupakan tahap awal untuk mengembangkan kemampuan membaca dan menulis, sedangkan kemampuan membuat coretan berhubungan erat dengan kematangan motorik halus anak usia dini (Seefeld \& Wasik, 2008: 266). Oleh sebab itu, kemampuan motorik halus anak usia 4-5 tahun dapat distimulasi dengan kegiatan seni rupa.

Kemampuan Motorik Halus Anak Usia 4-5 Tahuan

Aspek kemampuan motorik halus anak usia dini sangat penting dikembangkan karena berhubungan dengan kemampuan aspek perkembangan lainnya. Seefeld \& Wasik (2008: 66) menjelaskan bahwa pada anak usia 3-5 tahun dapat mengembangkan peningkatan kendali atas otot-otot halus anak. Pendapat Seefeld \& Wasik diatas menjelaskan bahwa pada anak usia 3-5 tahun tahun, kemampuan motorik halusnya sudah berkembang dengan baik.

$$
\text { Suyanto (2005: 50) }
$$

menjelaskan bahwa perkembangan motorik halus anak usia dini meliputi perkembangan otot halus dan fungsinya, dimana otot berfungsi untuk melakukan gerakan-gerakan bagian-bagian tubuh yang lebih spesifik seperti: menulis, melipat, meangkai, mengancing baju, mengikat tali sepatu, dan menggunting. Menurut Suyanto, perkembangan motorik halus anak usia dini dapat mendukung dalam melakukan kegiatan seharisehari. Menurut Allen dan Marotz (2010: 140), menyebutkan perkembangan motorik halus anak usia 4-5 tahun meliputi: (1) membangun menara dengan 10 balok atau lebih; (2) membentuk benda atau sesuatu dari lempung; (3) Meniru beberapa gambar bentuk dan tulisan beberapa huruf; (4) menggenggam krayon atau spidol dengan menggunakan genggaman 3 jari; (5) mewarnai dan menggambar; (6) semakin akurat dalam memukul paku dan pasak dengan palu; serta (7) merangkai manik-manik kecil dengan benang. Allen dan Marotz menyebutkan tugas perkembangan motorik halus anak usia 4-5 tahun meliputi 7 jenis tugas perkembanga yang bisa distimulasi melalui kegiatan pembelajaran. Dari berbagai pendapat ahli diatas dapat disimpulkan bahwa perkembangan kemampuan motorik halus anak meliputi otot halus, kekuatan jari, kelenturan pergelangan tangan, koordinasi mata dan tangan yang bisa difungsikan anak dalam membantu melakukan aktivitas seharihari.

\section{Seni Rupa Anak Usia Dini}

Pada pendidikan anak usia dini (PAUD) kegiatan bermain, bernyanyi, menggambar, menari, merupakan aktivitas seni yang sangat mendasar dimana seluruh aktivitas tersebut melibatkan seluruh indera dan membantu susunan saraf (Suyadi, 2015: 167). Seni pada pendidikan anak usia dini terbagi menjadi seni musik, gerak, dan rupa. Kegiatan seni 
pada anak usia dini dapat menstimulai berbagai aspek perkembanganngan anak, antara lain: kemampuan berpikir, kreativitas, literasi, kekuatan otot, dsb. Seni memiliki nilai estetika yang tinggi, tetapi pada anak usia dini seni atau kesenian memiliki nilai pendidikan. Nilai kesenian bagi anak usia 3-5 tahun salah satunya adalah untuk melakukan dan memperoleh kendali otot halus serta menguatkan motor tangan dan mata (Seefeld \& Wasik, 2008: 261). Menurut Seefeld \& Wasik, nilai kesenian dapat digunakan untuk menstimulasi kemampuan motorik halus dan menguatkan motor tangan dan mata pada anak usia dini.

Menurut Mulyani (2017: 6576) menjabarkan bahwa kegiatan pembelajaran seni rupa pada anak usia dini, meliputi: menggambar, finger painting, melukis, kolase, menjplak, membentuk, mencetak, mengecap, serta melipat. Mulyani menjelaskan bahwa kegiatan seni rupa pada anak usia dini merupakan kegiatan yang menyenangkan yang menghasilkan produk karya seni melalui kegiatan pembelajaran menggambar, finger painting, melukis, kolase, menjplak, membentuk, mencetak, mengecap, serta melipat dimana semua kegiatan tersebut dapat dihubungan dengan tema pembelajaran. Dari berbagai pendapat para ahli dapat disimpulkan bahwa kemampuan motorik halus anak usia dini dapat distimulasi dengan kegiatan seni rupa yang menyenangkan.

\section{METODE}

Pendekatan penelitian menggunakan pendekatan kualitatif, dengan jenis penelitian tindakan kelas. Model PTK yang digunakan adalah Kemmis \& Tagrat, yang terdiri dari empat tahapan pada setiap siklusnya, yaitu: perencanaan, pelaksanaan, observasi, dan refleksi.

Penelitian tindakan kelas dilaksanakan pada kelompok A (usia 4-5 tahun) di TK Negeri Pembina Surakarta. Subyek penelitian berjumlah 21 anak, yang terdiri dari 11 anak laki-laki dan 10 anak perempuan. Penelitian tindakan kelas dilaksanakan selama empat bulan dar bulan Juli-Oktober 2018. Penelitian tindakan kelas dilakukan dengan cara berkolaborasi dengan guru kelas.

Data penelitian berupa data kualitatif tentang kemampuan motorik halus anak usia 4-5 tahun. Sumber data dalam penelitian ini adalah guru dan anak. Teknik pengumpulan data menggunakan wawancara, dokumentasi, dan observasi selama pembelajaran. Uji validitas data menggunakan triangulasi tekni dan sumber data. Analisis data penelitian menggunakan model interaktif Milles \& Huberman, yang terdiri dari pengumpulan data, reduksi data, penyajian data, dan verifikasi data.

\section{HASIL DAN PEMBAHASAN}

Hasil penelitian membuktikan bahwa kemampuan motorik halus anak usia 4-5 tahun dapat distimulasi melalui kegiatan seni rupa. Penelitian yang dilakukan kelompok anak usia 45 tahun di TK Negeri Pembina Surakarta menggunakan penelitian tindakan kelas sebanyak 3 siklus. Masing-masing siklus diberikan kegiatan seni rupa yang beragam untuk menstimulasi semua insdikator kemampuan motorik halus anak, yaitu: koordinasi mata dan tangan, 
kelenturan pergelangan tangan, dan kekuatan otot-otot jari tangan.

Pada Siklus 1 kegiatan seni yang diterapkan untuk menstimulasi kemampuan motorik halus anak adalah membuat hasil karya kipas jari. Hasil karya ini dibuat dengan berbagai jenis kegiatan seni rupa, yaitu: menjiplak pola tangan, mewarnai, menggunting, dan menempel. Kegiatan ini bertujuan untuk mengembangkan indikator kelenturan pergelangan tangan serta koorrdinasi tangan dan mata. Hasil yang diperoleh dari stimulasi tersebut adalah kekuatan pergelangan tangan anak sudah baik, sedangkan korodinasi mata dan jari tangan anak masih butuh distimulasi. Hal ini dibuktikan pada hasil menjiplak jari tangan sudah sesuai pola, sedangan untuk hasil menggunting anak-anak masih belum sesuai pola dan masih membutuhkan bantuan guru.

Data hasil penelitian siklus 2 tentang kemampuan motorik halus anak dengan indikator koordinasi mata dan tangan; kelenturan pergelangan tangan; dan kekuatan dan kelenturan jari tangan distimulasi dengan jenis kegiatan seni rupa mengecap, figer painting, melelukis, meroce, menjiplak, menjumput, dan mewarnai. Kegiatan seni rupa diberikan dalam setiap area dan disesuaikan dengan tema. Dari berbagai jenis kegiatan seni rupa yang diberikan kepada anak diperoleh data bahwa kemampuan motorik halus anak semakin meningkat.

Pada siklus 3, jenis kegiatan seni rupa yang diberikan ke anak usia 4-5 tahun adalah menggenggap, membentuk, menempel, menggambar dan mewarnai. Berbagai jenis kegiatan seni rupa ini dapat menstimulasi kemampuan motorik halus anak. Ketiga indikator kemampuan motorik halus anak usia 4-5 tahun yang meliputi: koordinasi mata dan tangan, kelenturan pergelangan tangan, serta kekuatan dan kelenturan jari tangan anak meningkat. Hal ini terlihat dari kemampuan anak untuk menggunakan jari tangan dalam menjepit alat tulis atau krayon semakin kuat, membuat coretan gambar dan warna semakin terarah, bisa memperkiraan takaran ketikan menjumput. Beberapa hal tersebut membuktikan bahwa kemampuan motorik anak usia 4-5 tahun sudah meningkat. Hasil penelitian tersebut sesuai dengan pendapat Seefeld \& Wasik (2008: 66) yang menjelaskan bahwa pada anak usia 3-5 tahun dapat mengembangkan peningkatan kendali atas otot-otot halus anak.

Penerapan kegiatan seni rupa pada anak usia 4-5 tahun diimplikasikan dalam proses pembelajaran di setiap area. Kegiatan seni rupa dipadukan dengan kegiatan selain kegiatan seni, sehingga stimulasi yang diberikan untuk mengembangkan kemampuan motorik halus dapat terintegrasi dengan kemampuan dan kegiatan yang lain. Kegiatan seni rupa yang diterapkan pada peneletian ini adalah mewarnai, menggambar, melukis, figer painting, menjiplak, membentuk, menggunting, menempel, menggenggam, menjumput, menjepit, dan meronce. Berbagai kegiatan seni rupa yang diterapkan pada anak usia dini tersebut sesuai dengan pendapat Mulyani (2017: 65-76) yang menjabarkan bahwa kegiatan pembelajaran seni rupa pada anak usia dini, meliputi: menggambar, finger painting, melukis, kolase, menjplak, 
membentuk, mencetak, mengecap, serta melipat.

Berbagai kegiatan seni rupa tersebut diterapakan dalam kegiatan di area dan menghasilkan karya anak. Hasil penelitian membuktikan bahwa penerapan berbagai jenis kegiatan seni rupa tersebut dapat menstimulasi kemampuan motorik halus anak yang meliputi koordinasi mata dan tangan, kekuatan jari tangan dan kekuatan pergelangan tangan. Hasil penelitian ini sesuai dengan pendapat Suyadi (2015: 167) yang menyatakan bahwa aktivitas seni yang sangat mendasar dimana seluruh aktivitas tersebut melibatkan seluruh indera dan membantu susunan saraf.

\section{KESIMPULAN}

Kemampuan motorik halus anak usia 4-5 tahun, yang meliputi: koordinasi jari tangan dan mata, kekuatan otot-otot jari, kelenturan pergelangan tangan meningkat melalui stimulasi kegiatan seni menggambar, melukis, figer painting, mewarnai, meronce, mencetak, dan menggunting. Peningkatan kemampuan motorik halus anak usia 4-5 tahun dibuktikan dengan kemampuan anak dalam mengenggam, menjumput, dan menjepit alat tulis.

\section{DAFTAR PUSTAKA}

Allen, K. Eileen dan Marotzt, Lynn R. (2010). Profil Perkembangan Anak (Valentino). Jakarta: Indeks.

Kementerian Pendidikan dan Kebudayaan. (2015). Pedoman Penyusunan Kurikulum Tingkat Satuan Pendidikan (KTSP) Pendidikan Anak Usia Dini.
Jakarta: Direktorat Pembinaan

Pendidikan Anak Usia Dini.

Mulyani, Novi. (2017). Pengembangan Seni Anak Usia Dini. Jakarta: Rosda.

Seefeldt, Carol \& Wasik, Barbara A. (2008). Pendidikan Anak Usia Dini (Pius Nasar). Jakarta: Indeks.

Suyadi. (2015). Teori Pembelajaran Anak Usia Dini dalam Kajian Neurosains. Jakarta: Rosda.

Suyanto, Slamet. (2005). DasarDasar Pendidikan Anak Usia Dini. Yogyakarta: Hikayat.

Yamin, Martinis dan Sanan, Jamilah Sabri. (2013). Panduan PAUD. Jakarta: Referesi. 